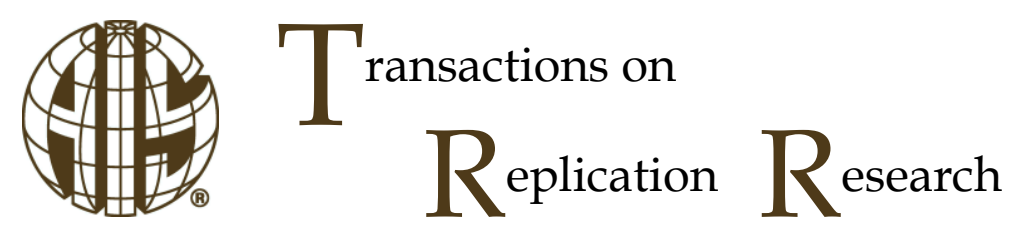

\title{
Information and Collective Mindfulness - A Methodological Replication Study
}

\author{
René Moquin \\ Department of Computer Information Technology, Arkansas State University \\ rmoquin@astate.edu
}

\begin{abstract}
:
This paper reinvestigates the cognitive theory of collective mindfulness on organizational Information Systems performance by conducting a methodological replication of Khan, Lederer, and Mirchandani's (2013) study. Collective mindfulness in the context of organizational information systems (IS) has significant effects on effectiveness and performance. We found that upper management concern and support for IS influences organizational performance through collective mindfulness. Upper management concern for typical and atypical situations and their associated repercussions on performance require solutions in real-time and concern for alternative problem-solving methods. Collective mindfulness addresses the notion of a more in-depth and purposeful analysis of potential catalysts negatively affecting performance. Future studies are encouraged to strengthen this study through construct improvement including the addition of relevant dimensions to collective mindfulness.
\end{abstract}

Keywords: Collective Mindfulness, Information Systems, Organizational Performance, Conceptual Replication

The manuscript was received 10/18/2017 and was with the authors 4 months for two revisions. 


\section{Introduction}

Organizations invest in information systems (IS) to improve organizational efficiency, decision making, and innovativeness (Trantopoulos, von Krogh, Wallin, \& Woerter, 2017). Top management's concern in achieving these goals requires a continual focus on potential and actual systemic errors, and their resolution (Butler \& Gray, 2006). For example, a highly contested hallmark of IS performance is information security. Within the last decade, several high-profile data breaches have occurred against companies like Target, Sony, and Equifax, which have resulted in billions of dollars in damages to both customers and organizations (DeSot, 2015; Peterson, 2014; Target, 2014). The cognitive theory of collective mindfulness addresses the need to assess IS performance and reliability (Butler \& Gray, 2006; Brown, Ryan, \& Creswell, 2007; Swanson \& Ramiller, 2004; Langer, 1989). Further, the notion of collective mindfulness addresses the continual vigilance on performance by addressing the need for organizations to monitor environmental and operational conditions and consider alternate perspectives, and understanding failures as a way to improve organizational performance and reliability (Butler \& Gray, 2006, p. 211). Khan, Lederer, and Mirchandani (2013) conducted a test of this theory by operationalizing its dimensions as asserted by Swanson and Ramiller (2004) and Butler and Gray (2006).

We performed a methodological replication process of the Khan et al. (2013) study by using a more extensive sample of respondents. We offer several contributions to this replication study. First, we found support for collective mindfulness to explain the motivations and behaviors of supportive management concerning mindful IS performance. Second, we used a larger sample size to test the model's nomology and found that the explanatory power was improved. Finally, we uncovered the potential to improve the formative collective mindfulness concepts based on the PLS-SEM analysis. We perceived that a closer examination of the formative dimensions could improve with a more in-depth investigatory process by adding and refining the measurement items.

The structure of this paper is as follows. We describe the research method, data collection, and analysis processes, followed by a comparison of our results to Kahn et al. (2013) results. Finally, we close with a discussion of the implications arising from our study and suggestions for future research.

\section{Research Hypotheses}

The primary objective of the current study was to test the methodological replicability of the Khan et al. (2013) research model, which focuses on understanding top management support and commitment to IS performance. The following are the hypotheses to be tested.

Hypotheses 1: The greater the top management support for information systems, the greater the preoccupation with information systems failure.

Hypotheses 2: The greater the top management support for information systems, the greater the reluctance to simplify information systems interpretations.

Hypotheses 3: The greater the top management support for information systems, the greater the sensitivity to information systems operations.

Hypotheses 4: The greater the top management support for information systems, the greater the commitment to information systems resilience.

Hypotheses 5: The greater the top management support for information systems, the greater the deference to information systems expertise.

Hypotheses 6: The greater the top management preoccupation with IS failure, the greater the IS performance.

Hypotheses 7: The greater the top management reluctance to simplify IS interpretations, the greater the IS performance.

Hypotheses 8: The greater the top management sensitivity to IS operations, the greater the IS performance. 
Hypotheses 9: The greater the top management commitment to IS resilience, the greater the information systems performance.

Hypotheses 10: The greater the top management deference to IS expertise, the greater the IS performance.

\section{Method}

A cross-sectional survey design facilitated by panel data from an organization specializing in Internet-based research serves as our data collection method. The management literature has successfully conducted this type of sampling, particularly when specific participant characteristics are required (Carlson, Ferguson, Hunter, \& Whitten, 2012; Judge, llies, \& Scott, 2006). All measurement items (table 2), scales, and respondent selection criteria were adopted from (Khan et al., 2013). A purposive sampling methodology was necessary to select respondents based on established criteria set by the original study (Mangal \& Mangal, 2013). The selection criteria include bounding the survey to the United States, 'for profit' organizations, and individuals in top management positions. 


\begin{tabular}{|c|c|c|c|c|c|}
\hline \multirow[b]{2}{*}{ Construct } & \multirow[b]{2}{*}{ Item } & \multicolumn{2}{|c|}{ Current Study } & \multicolumn{2}{|c|}{ Khan et al. (2013) } \\
\hline & & Mean & St. Dev & Mean & St. Dev \\
\hline \multicolumn{6}{|c|}{ Preoccupation with failure (PF) } \\
\hline PF1 & $\begin{array}{l}\text { Top management consistently looks for signals of trouble } \\
\text { even during times of smooth operation }\end{array}$ & 4.16 & 1.31 & 3.87 & 0.91 \\
\hline PF2 & $\begin{array}{l}\text { Top management is always alert for any signs of future } \\
\text { problems }\end{array}$ & 4.26 & 1.17 & 3.85 & 0.87 \\
\hline PF3 & $\begin{array}{l}\text { Top management is preoccupied with the possibility of } \\
\text { failure }\end{array}$ & 3.52 & 1.39 & 1.95 & 0.79 \\
\hline \multicolumn{6}{|c|}{ Reluctance to simplify interpretations } \\
\hline $\mathrm{RS} 1$ & $\begin{array}{l}\text { Top management believes complex responses are needed } \\
\text { in complex environments }\end{array}$ & 3.71 & 1.27 & 2.40 & 1.08 \\
\hline RS2 & $\begin{array}{l}\text { Top management believes general interpretations of events } \\
\text { or phenomena may not always apply to our organizational } \\
\text { situations }\end{array}$ & 3.66 & 1.17 & 3.54 & 0.84 \\
\hline RS3 & $\begin{array}{l}\text { Top management is open to new ideas even when they } \\
\text { come from outside our organization }\end{array}$ & 3.91 & 1.22 & 4.26 & 0.68 \\
\hline \multicolumn{6}{|c|}{ Sensitivity to operations } \\
\hline SOP1 & $\begin{array}{l}\text { Top management entertains the possibility of a high degree } \\
\text { of unreliability in the current operations }\end{array}$ & 3.61 & 1.30 & 2.40 & 0.96 \\
\hline \multicolumn{6}{|c|}{ Commitment to resilience } \\
\hline CR1 & $\begin{array}{l}\text { Top management believes it is difficult to identify and } \\
\text { develop contingency plans for every possibility }\end{array}$ & 3.63 & 1.17 & 3.21 & 1.06 \\
\hline CR2 & Top management favors improvisation over planning & 3.57 & 1.28 & 2.30 & 1.06 \\
\hline CR3 & Top management favors adaptation over routine & 3.87 & 1.09 & 3.07 & 0.90 \\
\hline CR4 & Top management favors effectiveness over efficiency & 3.99 & 1.01 & 3.34 & 0.82 \\
\hline CR5 & $\begin{array}{l}\text { Top management believes trade offs between schedule, } \\
\text { budget, and delivered functionality need creative adjustment }\end{array}$ & 3.94 & 0.97 & 3.48 & 0.89 \\
\hline CR6 & $\begin{array}{l}\text { Top management believes inevitable surprises and mistakes } \\
\text { in new undertakings are opportunities to learn }\end{array}$ & 4.02 & 0.92 & 4.15 & 0.70 \\
\hline \multicolumn{6}{|c|}{ Deference to expertise } \\
\hline DE1 & $\begin{array}{l}\text { Top management believes, in times of crisis, the authority of } \\
\text { action should flow to individuals and units with the relevant } \\
\text { expertise in the problem at hand }\end{array}$ & 4.08 & 0.93 & 4.22 & 0.66 \\
\hline DE2 & $\begin{array}{l}\text { Top management believes formal structures within the } \\
\text { organization may be relaxed so that expertise is given } \\
\text { priority over rank or departmental boundaries }\end{array}$ & 3.85 & 0.99 & 3.87 & 0.83 \\
\hline $\begin{array}{l}\text { DE3 } \\
\text { Information }\end{array}$ & $\begin{array}{l}\text { Top management defers to expertise over rank } \\
\text { Systems Performance }\end{array}$ & 3.93 & 1.05 & 4.05 & 0.69 \\
\hline ISP_1 & $\begin{array}{l}\text { End-users recognize the benefits of our IS function's } \\
\text { services }\end{array}$ & 4.07 & 0.97 & 3.89 & 0.79 \\
\hline ISP_2 & $\begin{array}{l}\text { Our IS function is perceived as facilitating better decision } \\
\text { making }\end{array}$ & 4.06 & 0.93 & 3.80 & 0.78 \\
\hline ISP_3 & $\begin{array}{l}\text { End-users are generally satisfied with the services of the IS } \\
\text { function }\end{array}$ & 4.13 & 0.89 & 3.87 & 0.77 \\
\hline ISP_4 & $\begin{array}{l}\text { The use of IS services has led to better management of } \\
\text { organizational activities }\end{array}$ & 4.18 & 0.86 & 4.00 & 0.66 \\
\hline ISP_5 & $\begin{array}{l}\text { Our IS function has failed to meet end-user performance } \\
\text { expectations }\end{array}$ & 3.49 & 1.36 & 2.02 & 0.88 \\
\hline \multicolumn{6}{|c|}{ Top Management Support } \\
\hline TMS_1 & Top management involvement with IS function is strong & 4.13 & 1.00 & 3.97 & 0.92 \\
\hline TMS_2 & Top management is interested in IS function & 4.25 & 0.81 & 4.23 & 0.63 \\
\hline TMS_3 & Top management understands the importance of IS & 4.12 & 0.89 & 4.45 & 0.65 \\
\hline TMS_4 & Top management supports the IS function & 4.05 & 0.85 & 4.34 & 0.60 \\
\hline TMS_5 & Top management considers IS as a strategic resource & 4.04 & 0.96 & 4.35 & 0.57 \\
\hline TMS_6 & Top management understands IS opportunities & 3.91 & 1.11 & 3.98 & 0.87 \\
\hline TMS_7 & $\begin{array}{l}\text { Top management keeps the pressure on operating units to } \\
\text { work with IS }\end{array}$ & 4.07 & 0.97 & 4.37 & 0.65 \\
\hline
\end{tabular}




\section{Findings}

One hundred and three participants completed the survey. There were no missing data cases, and thus all data were usable for a 100\% response rate. Fifty-five of the participants were male, 45 were female, and three preferred not to disclose their gender. Approximately 96 percent of the respondents achieved education beyond high school with 54 percent attaining a graduate degree. The majority of participants worked in technology $(25 \%)$, manufacturing $(17 \%)$, and real estate $(10 \%)$. The majority of age groups ranged from 20-49 (88\%). Thirty-five percent were in the c-suite (CIO, CTO, \& COO), $26 \%$ were in the president/CEO position, $18 \%$ were owners, $16 \%$ were in the vice-president position, and $5 \%$ were in the role of senior vice-president.

\subsection{Reflective Construct Assessment}

The research model for the current study was analyzed using partial least squares structural equation modeling (PLS-SEM) techniques via SmartPLS 3 software (Ringle, Wende, \& Becker, 2015). PLS-SEM assesses the psychometric properties of the measurement items and in modeling the relationships among the independent and latent dependent variables simultaneously. PLS is a correlational-based parametric method with fewer stringent assumptions on data distribution.

The research model for this study contains both reflective and formative items. We assessed the reflective items first followed by the formative items. The reflective assessment process begins by measuring reliability through Cronbach's alpha (CA), composite reliability (CR), and convergent and discriminant validity. Cronbach's alpha evaluates internal consistency in which measurement items should correlate and consistently measure what they purport to measure (Straub, Boudreau, \& Gefen, 2004). Table 3 presents the CA, CR, and average variance extracted (AVE) results. The CA values were within the recommended minimum acceptable value of 0.70 (Nunnally, 1978). A shortfall of Cronbach's alpha is that it tends to underestimate internal consistency because of "its sensitivity to the number of items in the scale" (Hair Jr., Hult, Ringle, \& Sarstedt 2017, p.111). Composite reliability addresses this limitation by examining the items' outer loadings (Hair Jr. et al. 2017). The CR values were within the suggested threshold of 0.60 (Bagozzi \& $\mathrm{Yi}, 1988$ ). Convergent validity measures the amount of error-free variance in a set of measurements captured by their assigned construct through average variance extracted (AVE). The AVE results appear to capture at least $50 \%$ of the measurement variance (Fornell \& Larcker, 1981; Hair Jr. et al. 2017).

\begin{tabular}{|l|l|l|l|l|}
\hline \multicolumn{5}{|c|}{ Table 3. Reliability Results } \\
\hline Variable & CA & CR & AVE & Sqrt/AVE \\
\hline IS Performance & 0.769 & 0.851 & 0.589 & 0.767 \\
\hline Top Management Support & 0.775 & 0.847 & 0.527 & 0.725 \\
\hline $\begin{array}{l}\text { CA }=\text { Cronbach's Alpha } \\
\text { CR }=\text { Composite Reliability } \\
\text { AVE }=\text { Average Variance Extracted } \\
\text { Sqrt/AVE = Square root of the Average Variance Extracted }\end{array}$ & \\
\hline
\end{tabular}

Convergent validity occurs when measurement items thought to theoretically reflect a given construct converge on their assigned factor (Hair Jr. et al. 2017). Table 4 indicates that most of the reflective indicators appeared to load higher on their associated construct and satisfied the minimum recommended value of 0.70 (Gefen, Straub, \& Boudreau, 2000). ISP1 appears to load high on the TMT construct (.717). However, ISP1 loads at least $10 \%$ less on other constructs thus satisfying the convergent validity requirements (Gefen \& Straub, 2005). Items TMS5 and ISP5 loaded well below the recommended minimum of 0.70 . As a result, each item was removed independently and the model re-run to note any effects. No significant effects were present.

Discriminant validity assesses the uniqueness of a construct measuring a phenomenon that is uncaptured by other constructs in a given model (Hair, Jr., et al. 2017). Construct measurement items should load higher on their associated construct than with other items. Table 4 shows that items loaded higher on their associated construct than with others. 


\begin{tabular}{|l|l|l|l|}
\hline \multicolumn{4}{|c|}{ Table 4. Cross Loadings } \\
\hline Variable & TMS & ISP & VIF \\
\hline TMS1 & $\mathbf{0 . 7 5 6}$ & 0.524 & 1.688 \\
\hline TMS2 & $\mathbf{0 . 6 5 8}$ & 0.506 & 1.426 \\
\hline TMS3 & $\mathbf{0 . 6 7 6}$ & 0.523 & 1.362 \\
\hline TMS6 & $\mathbf{0 . 7 8 4}$ & 0.506 & 1.654 \\
\hline TMS7 & $\mathbf{0 . 6 6 6}$ & 0.531 & 1.386 \\
\hline ISP1 & 0.715 & $\mathbf{0 . 8 4 1}$ & 1.326 \\
\hline ISP2 & 0.459 & $\mathbf{0 . 7 3 5}$ & 1.670 \\
\hline ISP3 & 0.519 & $\mathbf{0 . 7 4 9}$ & 1.408 \\
\hline ISP4 & 0.427 & $\mathbf{0 . 7 4 0}$ & 1.643 \\
\hline $\begin{array}{l}\text { TMS = Top Management Support } \\
\text { ISP = Information Systems Performance } \\
\text { VIF = Variance Inflation Factor }\end{array}$ & & \\
\hline
\end{tabular}

\subsection{Formative Construct Validity}

The mindfulness constructs for this study are formative, which requires a different methodology for assessing construct validity (Chin, 1998). We begin the formative validity process by assessing multicollinearity and item significance. Unlike reflective constructs, formative measures are not interchangeable and thus exhibit minimal if any collinearity. High multi-collinearity indicates a conceptual overlap between two or more measurement items (Cenfetelli \& Bassellier, 2009). One method to measure multicollinearity involves the variance inflation factor (VIF). Table 5 shows that the VIF value for all formative items was below the recommended 3.33 threshold (Diamantopoulos \& Siguaw, 2006). We, therefore, perceived no multi-collinearity issues.

Another measure of construct validity is the assessment of item significance and relevance on their associated formative construct. According to Cenfetelli \& Bassellier (2009) and Hair Jr. et al. (2017), the outer weights of each formative measurement signify its relative contribution to its associated construct. We executed the bootstrap procedure using 5000 subsamples with the no sign change option set and the PLS algorithm to measure the outer weights, (Hendeler, Ringle, \& Sinkovics, 2009; Hair Jr. et al., 2017). Table 5 shows that measurement item CR6 (.563) contributes most to Commitment to resilience followed by CR5, CR4, and CR3. DE1 (.542) contributes most to Deference to Expertise, followed by DE2, and DE3. PF2 (0.514) contributes most to Preoccupation to Failure, followed by PF3, and PF1. RS3 (0.765) contributes most to Reluctance to Simplify Interpretations followed by RS1 and RS4. SO1 (.628) contributes most to Sensitivity to Operations followed by SO2. Items with a non-significant weight do not necessarily imply that they should be dropped (Hair Jr. et al. 2017). However, items with a non-significant outer weight and a loading value less than .50 are candidates for removal from the model (Hair Jr. et al. 2017). Therefore, formative items CR1 (.381) and RS2 (.421) were removed because of their low loading values and insignificant outer weights. We, therefore, perceive that while the majority of formative items contribute appropriately to the model, measurement items CR1 and RS2 require further examination. 


\begin{tabular}{|c|c|c|c|c|c|}
\hline Variables & $\begin{array}{c}\text { Outer } \\
\text { Loading }\end{array}$ & $\begin{array}{c}\text { Outer } \\
\text { Weight }\end{array}$ & $\begin{array}{c}\mathrm{t}- \\
\text { statistic }\end{array}$ & $\begin{array}{c}\mathrm{p}- \\
\text { value }\end{array}$ & VIF \\
\hline CR2 -> Commitment to IS resilience & 0.541 & -0.069 & 0.450 & 0.652 & 1.796 \\
\hline CR3 -> Commitment to IS resilience & 0.673 & 0.043 & 0.215 & 0.830 & 2.251 \\
\hline CR4 -> Commitment to IS resilience & 0.760 & 0.337 & 1.629 & 0.103 & 1.582 \\
\hline CR5 -> Commitment to IS resilience & 0.781 & 0.332 & 1.847 & 0.065 & 1.842 \\
\hline CR6 -> Commitment to IS resilience & 0.875 & 0.563 & $3.470^{* * *}$ & 0.001 & 1.624 \\
\hline DE1 -> Deference to IS expertise & 0.861 & 0.542 & $3.719^{* * *}$ & 0.000 & 1.416 \\
\hline DE2 -> Deference to IS expertise & 0.855 & 0.532 & $3.552^{* * *}$ & 0.000 & 1.402 \\
\hline DE3 -> Deference to IS expertise & 0.556 & 0.142 & 0.940 & 0.347 & 1.248 \\
\hline PF1 -> Preoccupation with IS failure & 0.780 & 0.320 & 1.004 & 0.316 & 1.596 \\
\hline PF2 -> Preoccupation with IS failure & 0.877 & 0.514 & $1.936^{*}$ & 0.053 & 1.668 \\
\hline PF3 -> Preoccupation with IS failure & 0.745 & 0.403 & $2.170^{*}$ & 0.030 & 1.264 \\
\hline RS1 -> Reluctance to simplify IS interpretations & 0.697 & 0.293 & 1.367 & 0.172 & 1.462 \\
\hline RS3 -> Reluctance to simplify IS interpretations & 0.937 & 0.765 & $4.443^{\star * \star}$ & 0.000 & 1.249 \\
\hline RS4 -> Reluctance to simplify IS interpretations & 0.516 & 0.153 & 0.848 & 0.396 & 1.299 \\
\hline SO1 -> Sensitivity to IS operations & 0.864 & 0.628 & $3.241^{* \star *}$ & 0.001 & 1.221 \\
\hline SO2 -> Sensitivity to IS operations & 0.823 & 0.556 & $2.667^{* *}$ & 0.008 & 1.221 \\
\hline
\end{tabular}

\subsection{Formative Construct}

The results of the structural model appear in Figure 1. In accordance with the original design, TMS is the independent variable to PF, RSI, SO, CR, and DE, which are the dependent variables. Based on the test of the hypotheses, TMS positively influences PF (H1, $\beta=.41, p<.001)$, RSI $(\mathrm{H} 2, \beta=.50, p<.001)$, SO (H3, $\beta=.41, p<.001), C R(H 4, \beta=.49, p<.001)$, and DE (H5, $\beta=.64, p<.001)$. TMS also explains $17 \%, 25 \%$, $17 \%, 25 \%$, and $41 \%$ of the variance in its associated dependent variables.

The second test of the structural model involves the formative constructs as independent variables on ISP as the single dependent variable. The results indicate that PF does not influence ISP (H6, $\beta=.24$, ns). RSI does not influence ISP $(\mathrm{H} 7, \beta=-.03$, ns). SO does not influence ISP $(\mathrm{H} 8, \beta=-.05$, ns). CR positively influences ISP $(H 9, \beta=.30, p<.01)$, and DE positively influences ISP $(H 10, \beta=.36, p<.001)$. Further, the formative constructs explain $51 \%$ of the variance in ISP. 


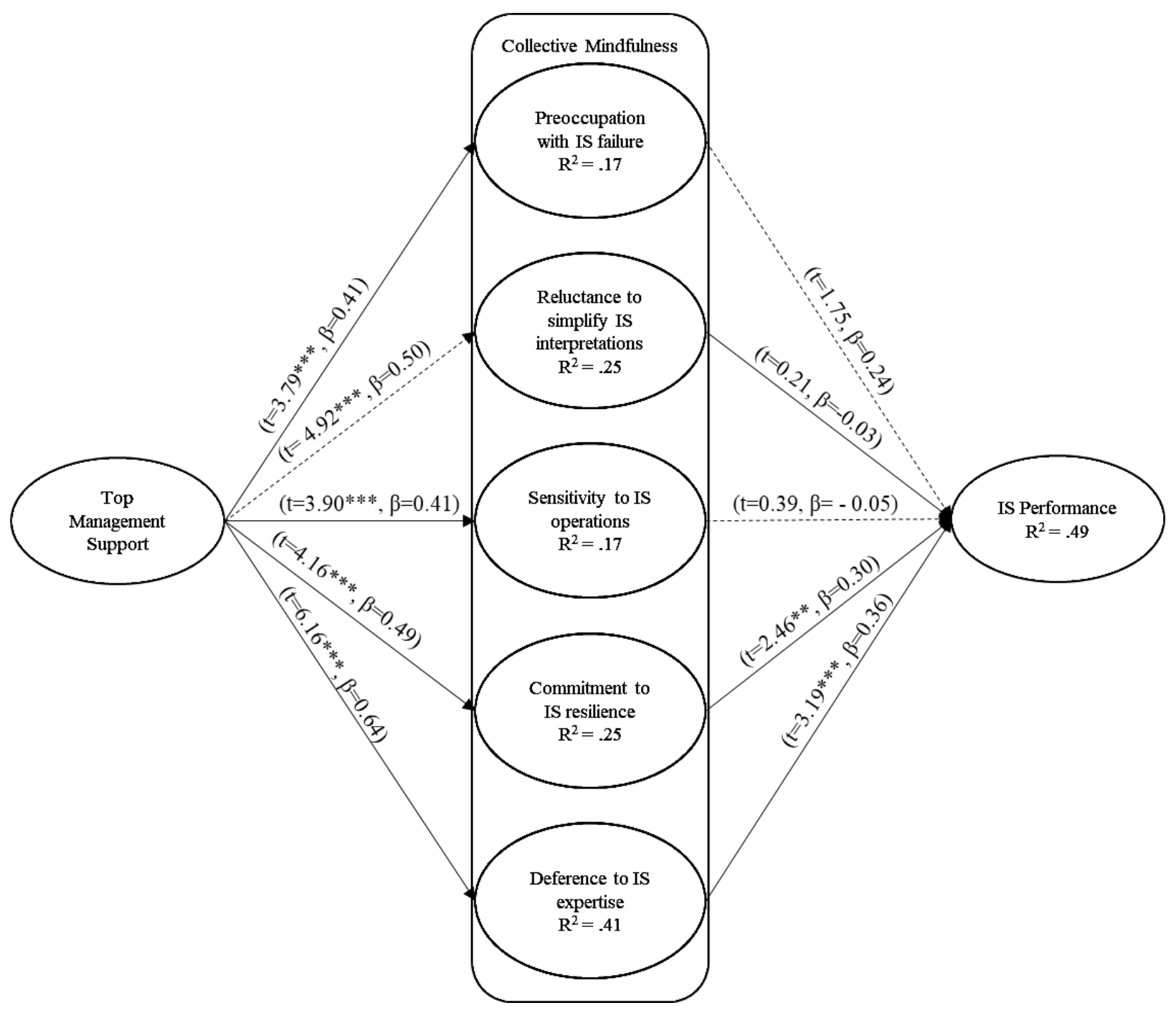

Figure 1. Structural Model Results

\section{Discussion and Conclusion}

The summarization of the study's findings appears in Table 6. The Khan et al. (2013) study hypothesized that top management support $(\mathrm{H} 1-\mathrm{H} 5)$ leads to collective mindfulness. Further, the higher top management support in collective mindfulness, the greater the IS performance $(\mathrm{H} 6-\mathrm{H} 10)$. While the hypotheses $(\mathrm{H} 1-\mathrm{H} 5)$ appear to support this assertion, it is clear that only a small portion of the collective mindfulness constructs support IS performance. We perceive that our study reasonably replicates Khan et al. (2013) findings with some concessions. First, an appropriate respondent sample should be at least ten times the largest number of paths to any single construct ( 5 in our model) to ensure appropriate power to detect significant relationships (Hair Jr., Black, Babin, \& Anderson, 2010). Regarding the number of paths, a sample size of 55 is the minimum to achieve $80 \%$ power with an $\mathrm{R}^{2}$ of $25 \%$ in ISP, at 0.05 significance level (Hair Jr. et al. 2017). Thus, our sample size is sufficient. Khan et al. (2013) conducted their study on a sample of 47 chief executive officers (CEOs) using a model, in the absence of more confirming information, that required a sample size of at least 55 for statistical significance (Hair Jr. et al. 2017). 


\begin{tabular}{|c|c|c|c|c|c|c|c|c|c|c|}
\hline \multicolumn{11}{|c|}{ Table 6. Model Results ${ }^{1}$} \\
\hline \multirow[b]{2}{*}{$\mathrm{H}$} & \multirow[b]{2}{*}{$\begin{array}{l}\text { Independent } \\
\text { Construct }\end{array}$} & \multirow[b]{2}{*}{$\begin{array}{l}\text { Dependent } \\
\text { Construct }\end{array}$} & \multicolumn{4}{|c|}{ Current Study } & \multicolumn{4}{|c|}{ Khan et al. (2013) } \\
\hline & & & $\mathrm{R}^{2}$ & Path & T-value & Result & $\mathrm{R}^{2}$ & Path & T-value & Result \\
\hline 1 & \multirow{4}{*}{$\begin{array}{l}\text { Top Management } \\
\text { Support }\end{array}$} & $\begin{array}{l}\text { Preoccupation with } \\
\text { IS failure }\end{array}$ & 0.17 & 0.41 & $3.79^{* \star *}$ & supported & 0.31 & 0.44 & $2.70^{* *}$ & supported \\
\hline 2 & & $\begin{array}{l}\text { Reluctance to } \\
\text { simplify IS } \\
\text { interpretations }\end{array}$ & 0.25 & 0.50 & $4.92^{* * *}$ & supported & 0.31 & 0.45 & $2.28^{*}$ & supported \\
\hline 3 & & $\begin{array}{l}\text { Sensitivity to IS } \\
\text { operations }\end{array}$ & 0.17 & 0.41 & $3.90^{* \star \star}$ & supported & 0.51 & 0.67 & $4.65^{\star \star \star}$ & supported \\
\hline 4 & & $\begin{array}{l}\text { Commitment to IS } \\
\text { resilience }\end{array}$ & 0.25 & 0.50 & $4.16^{* * *}$ & supported & 0.38 & -0.50 & $2.34^{*}$ & $\begin{array}{l}\text { not } \\
\text { supported }\end{array}$ \\
\hline 5 & & $\begin{array}{l}\text { Deference to IS } \\
\text { expertise }\end{array}$ & 0.41 & 0.64 & $6.16^{* \star \star}$ & Supported & 0.45 & 0.50 & $3.02^{\star *}$ & supported \\
\hline 6 & $\begin{array}{l}\text { Preoccupation with } \\
\text { IS failure }\end{array}$ & \multirow{5}{*}{ IS Performance } & 0.49 & 0.24 & 1.75 & $\begin{array}{l}\text { not } \\
\text { supported } \\
\end{array}$ & 0.45 & 0.09 & 0.33 & $\begin{array}{l}\text { not } \\
\text { supported }\end{array}$ \\
\hline 7 & $\begin{array}{l}\text { Reluctance to } \\
\text { simplify IS } \\
\text { interpretations }\end{array}$ & & 0.49 & -0.03 & 0.21 & $\begin{array}{l}\text { not } \\
\text { supported }\end{array}$ & 0.45 & 0.20 & 0.83 & $\begin{array}{l}\text { not } \\
\text { supported }\end{array}$ \\
\hline 8 & $\begin{array}{l}\text { Sensitivity to IS } \\
\text { operations }\end{array}$ & & 0.49 & -0.05 & 0.39 & $\begin{array}{l}\text { not } \\
\text { supported }\end{array}$ & 0.45 & 0.45 & $2.13^{*}$ & Supported \\
\hline 9 & $\begin{array}{l}\text { Commitment to IS } \\
\text { resilience }\end{array}$ & & 0.49 & 0.30 & $2.46^{* *}$ & supported & 0.45 & -0.11 & 0.58 & $\begin{array}{l}\text { not } \\
\text { supported }\end{array}$ \\
\hline 10 & $\begin{array}{l}\text { Deference to IS } \\
\text { expertise }\end{array}$ & & 0.49 & 0.36 & $3.19^{* \star \star}$ & supported & 0.45 & -0.03 & 0.13 & $\begin{array}{l}\text { not } \\
\text { supported }\end{array}$ \\
\hline \multirow{4}{*}{\multicolumn{3}{|c|}{${ }^{*} \mathrm{p} \leq .05,{ }^{* *} \mathrm{p} \leq .01,{ }^{* * *} \mathrm{p} \leq .001$}} & \multicolumn{4}{|c|}{$N=103$} & \multicolumn{4}{|c|}{$\mathrm{N}=47$} \\
\hline & & & \multicolumn{4}{|c|}{ Online survey/panel data } & \multicolumn{4}{|c|}{ Online and Written survey } \\
\hline & & & \multicolumn{4}{|c|}{ Partial Least Squares } & \multicolumn{4}{|c|}{ Partial Least Squares } \\
\hline & & & \multicolumn{4}{|c|}{ SmartPLS V3.2.7 } & \multicolumn{4}{|c|}{ PLS-Graph v.3.00 } \\
\hline
\end{tabular}

A second interesting finding involved the content of the formative measurement items. We performed a literature review to ascertain the operationalization of the mindfulness concepts and related topics. In concordance with Khan et al.'s (2013), we found no operationalized instruments for the mindfulness constructs in the literature review, which potentially explains the need for their development. Since formative items cause the construct and are not interchangeable (Hair Jr. et al. 2017), establishing content validity may partly explain some of the differences between studies. Content validity involves determining if the measurement items truly and unequivocally represent the construct (Straub, Boudreau, \& Gefen 2004). While the original study documented the methodology used to create the constructs, it is likely that additional investigation is necessary to account for previously undiscovered dimensions.

Another interesting finding was the support of three hypotheses that were unsupported in the original study. Hypothesis 4 asserted that the greater the top management support for information systems, the greater the commitment to information systems resilience. Our results show that hypothesis 4 was supported $(t=4.16, \beta=.50, p<.001)$. While it is possible that the increased sample size supported the hypothesis, the formative measurement items require focus. The original study did not incorporate a global reflective measure for the formative construct thus negating the ability to conduct a redundancy analysis (Chin, 1998; Hair Jr. et al., 2017). Except for CR1, the outer loadings for the remaining CR items were above the minimum threshold of .50 . However, only one item was statistically significant $(\mathrm{CR} 6 \mathrm{t}=$ $3.470, p \leq .001)$. Further, CR2's outer weight $(-0.069)$ suggested a suppressor effect indicating possible collinearity with other items (Cenfetelli \& Bassellier, 2009). However, the VIF results suggest no multicollinearity issues thus supporting the items retention.

${ }^{1}$ The bolded items represent the differences between the hypotheses of our study and Khan et al., 2013). 
Hypothesis 8 asserted that the greater the top management sensitivity to IS operations, the greater the IS performance ( $t=.19, \beta=.02$, ns). Sensitivity to Operations (SO) refers to the ability of an organization to focus on small details during day-to-day operations. It is the concern that significant problems usually appear from overlooking small issues (Swanson \& Ramiller 2004). The results for the SO items (c.f. Table 5), appear to exhibit statistical issues. However, an examination of the literature appears to refer to this dimension globally, which is evident in the SO items. A critical point Swanson and Ramiller (2004) suggest that SO applies to situations requiring "extreme time pressure" (p. 560). Therefore, it is likely that the SO construct lacks specificity. Further research should examine this dimension by focusing on organizations that deal with time-sensitive decisions.

Finally, we confirmed support for hypotheses $9(t=2.46, \beta=.30, p<.05)$, which asserts that the greater the top management commitment to IS resilience, the greater the information systems performance.

Hypothesis 10 is supported $(t=3.19, \beta=.36, p<.05)$, which asserts that the greater the top management deference to IS expertise, the greater the IS performance. The CR item issues notwithstanding, DE1 and DE2 appear to be measuring the same condition (1) that only experts with the most knowledge on a particular situation handle the issue and (2) that management should relax its structural boundaries to support the former. However, Swanson and Ramiller (2004) caution that "care must be taken not to conceptualize expertise too narrowly" (p. 561) and it is "about attending to the innovation with reasoning grounded in the firm's own facts and specifics" (p.561). The three items making up the Deference to expertise construct may be devoid of additional dimensions creating a conflicting replication stability issue.

A final note regarding the replication of the Khan et al. (2013) study involves the configuration of the collective mindfulness constructs. While the results of the constructs as formative indicate construct dimensionality (c.f. Table 5) and loadings (> .70), it may be possible to arrange the items as reflective. Therefore, we conducted a post hoc analysis by switching the collective mindfulness constructs to reflective indicators. Table 7 presents a comparison of all three models. The results show that when modeling the collective mindfulness constructs as reflective, the model remains consistent except one hypothesis. Hypothesis 6 posits that the greater the top management preoccupation with IS failure, the greater the IS performance. The results show that with reflective indicators, $\mathrm{H} 6$ is supported such that in the original and replicated models, this was not the case. 


\begin{tabular}{|c|c|c|c|c|c|c|c|c|c|c|c|c|c|c|}
\hline \multicolumn{15}{|c|}{ Table 7. Model Results ${ }^{2}$} \\
\hline \multirow[b]{2}{*}{$\mathrm{H}$} & \multirow[b]{2}{*}{ IV } & \multirow[b]{2}{*}{ DV } & \multicolumn{4}{|c|}{ Current Study-Formative } & \multicolumn{4}{|c|}{ Current Study-Reflective } & \multicolumn{4}{|c|}{ Khan et al. (2013) } \\
\hline & & & $\mathrm{R}^{2}$ & Path & T-value & Result & $\mathrm{R}^{2}$ & Path & T-value & Result & $R^{2}$ & Path & T-value & Result \\
\hline 1 & \multirow{4}{*}{ TMS } & PF & 0.17 & 0.41 & $3.79^{* * *}$ & supported & 0.16 & 0.41 & $3.70^{\star \star \star}$ & supported & 0.31 & 0.44 & $2.70^{\star \star}$ & supported \\
\hline 2 & & RS & 0.25 & 0.50 & $4.92^{* * *}$ & supported & 0.23 & 0.48 & $4.87^{\star \star \star}$ & supported & 0.31 & 0.45 & $2.28^{*}$ & supported \\
\hline 3 & & so & 0.17 & 0.41 & $3.90^{\star \star *}$ & supported & 0.17 & 0.41 & $4.05^{\star * *}$ & supported & 0.51 & 0.67 & $4.65^{\star \star \star}$ & supported \\
\hline 4 & & CR & 0.25 & 0.50 & $4.16^{\star \star \star}$ & supported & 0.19 & 0.44 & $3.95^{\star \star *}$ & supported & 0.38 & -0.50 & $2.34^{*}$ & $\begin{array}{l}\text { not } \\
\text { supported }\end{array}$ \\
\hline 5 & & DE & 0.41 & 0.64 & $6.16^{\star \star *}$ & Supported & 0.39 & 0.63 & $5.99^{\star \star *}$ & supported & 0.45 & 0.50 & $3.02^{\star *}$ & supported \\
\hline 6 & PF & \multirow{5}{*}{ ISP } & 0.49 & 0.24 & 1.75 & $\begin{array}{l}\text { not } \\
\text { supported }\end{array}$ & 0.49 & 0.30 & $1.98^{*}$ & supported & 0.45 & 0.09 & 0.33 & $\begin{array}{l}\text { not } \\
\text { supported }\end{array}$ \\
\hline 7 & RS & & 0.49 & -0.03 & 0.21 & $\begin{array}{l}\text { not } \\
\text { supported }\end{array}$ & 0.49 & -0.08 & 0.49 & $\begin{array}{l}\text { not } \\
\text { supported }\end{array}$ & 0.45 & 0.20 & 0.83 & $\begin{array}{l}\text { not } \\
\text { supported }\end{array}$ \\
\hline 8 & SO & & 0.49 & -0.05 & 0.39 & $\begin{array}{l}\text { not } \\
\text { supported }\end{array}$ & 0.49 & -0.07 & 0.56 & $\begin{array}{l}\text { not } \\
\text { supported }\end{array}$ & 0.45 & 0.45 & $2.13^{*}$ & supported \\
\hline 9 & CR & & 0.49 & 0.30 & $2.46^{\star *}$ & supported & 0.49 & 0.30 & $2.35^{*}$ & supported & 0.45 & -0.11 & 0.58 & $\begin{array}{l}\text { not } \\
\text { supported }\end{array}$ \\
\hline 10 & DE & & 0.49 & 0.36 & $3.19^{* * \star}$ & supported & 0.49 & 0.37 & $3.23^{* *}$ & supported & 0.45 & -0.03 & 0.13 & $\begin{array}{l}\text { not } \\
\text { supported }\end{array}$ \\
\hline & & & \multicolumn{4}{|c|}{$N=103$} & \multicolumn{4}{|c|}{$N=103$} & \multicolumn{4}{|c|}{$N=47$} \\
\hline & & & \multicolumn{4}{|c|}{ Online survey/panel data } & \multicolumn{4}{|c|}{ Online survey/panel data } & \multicolumn{4}{|c|}{ Online and Written survey } \\
\hline & & & \multicolumn{4}{|c|}{ Partial Least Squares } & \multicolumn{4}{|c|}{ Partial Least Squares } & \multicolumn{4}{|c|}{ Partial Least Squares } \\
\hline & & & \multicolumn{4}{|c|}{ SmartPLS V3.2.7 } & \multicolumn{4}{|c|}{ SmartPLS V3.2.7 } & \multicolumn{4}{|c|}{ PLS-Graph v.3.00 } \\
\hline \multicolumn{15}{|c|}{$\begin{array}{l}\text { IV = Independent Variable } \\
\text { DV = Dependent Variable } \\
\text { H = Hypothesis } \\
\text { TMS = Top Management St }\end{array}$} \\
\hline
\end{tabular}

\section{Limitations and Future Research}

We identified four limitations to consider in interpreting our results. First, applying the current findings to organizations that are concerned with collective mindfulness are tenuous because the real extent to which these respondents are representative of most organizations is unknown. For example, Weick and Sutcliffe (2001) reference high-reliability organizations (HRO) as dealing with potential life and death situations such as naval operations, and healthcare. However, it is likely that E-commerce organizations such as Amazon, E*Trade, and Netflix, though not life affecting, are taxonomically HRO's. While we did not specifically target HRO's in our study, it is probable that organizations that fit this profile might make the findings less generalizable.

${ }^{2}$ The bolded items represent the differences between the hypotheses of our study and Khan et al., 2013). 
Second, while Khan et al. (2013) provided information on the research methodology, there appears to be an opportunity to refine the collective mindfulness dimensions. For example, with the exception of the Deference to IS expertise construct, the coefficient of determination results exhibit a weak effect (Hair Jr. et al. 2017). The development of the formative measurement items stems from a somewhat limited literature review and an expert panel. Further, only a single pilot test was conducted to test the items and likely raises a concern for content validity (Straub, Boudreau, \& Gefen, 2004).

Third, it is unknown whether the nomology fully captures the representation of each item based on the evidence in the formative assessment tests. Future studies should focus on investigating and improving the dimensions comprising the collective mindfulness formative constructs. It is also likely that additional constructs can further refine the model's cohesiveness. We encourage future research to replicate this study by seeking broader national and international organizations with a more significant impact on the marketplace and society to determine the model's stability.

Finally, care must be observed when interpreting the post hoc results. While it is possible to argue for configuring collective mindfulness as reflective, future research should conduct appropriate construct analyses.

\section{Acknowledgments}

The author is grateful to the review team for their constructive and insightful suggestions. 


\section{References}

Bagozzi, R., \& Yi, Y. (1988). On the evaluation of structure equation models. Journal of the Academy of Marketing Science, 16(1), 74-94.

Brown, K. W., Ryan, R. M., \& Creswell, J. D. (2007). Mindfulness: Theoretical Foundations and evidence for its salutary effects. Psychological Inquiry, 18(4), 211-237.

Butler, B. S., \& Gray, P. H. (2006). Reliability, Mindfulness, and information systems. MIS Quarterly, 30(2), 211-224.

Carlson, D., Ferguson, M., Hunter, E., \& Whitten, D. (2012). Abusive supervision and work-family conflict: The path through emotional labor and burnout. The Leadership Quarterly, 23(5), 849-859.

Cenfetelli, R. T., \& Bassellier, G. (2009). Interpretation of formative measurement in information systems research. MIS Quarterly, 33(4), 689-708.

Chin, W. (1998). The partial least squares approach for structural equation modeling. In G. A. Marcoulides, Modern Methods for Business Research (pp. 295-336). Mahwah, NJ: Lawrence Erlbaum Associates.

DeSot, T. (2015, September 15). 8 Lessons to learn from the Sony Breach. Retrieved from Security: http://www.securitymagazine.com/articles/86649-lessons-to-learn-from-the-sony-breach

Diamantopoulos, A., \& Siguaw, J. (2006). Formative vs. reflective indicators in measure development: Does the choice of indicators matter? British Journal of Management, 13, $263-282$.

Fornell, C., \& Larcker, D. (1981). Evaluating structural equation models with unobservable variables and measurement error. Journal of Marketing Research, 18(1), 39-50.

Gefen, D., Straub, D., \& Boudreau, M. (2000). Structural equation modeling and regression: Guidelines for research practice. Communications of the Association for Information Systems, 4, 1-77.

Hair Jr., J. F., Black, W. C., Babin, B. J., \& Anderson, R. E. (2010). Multivariate data analysis 7e. Upper Saddle River, NJ: Pearson Prentice Hall.

Hair Jr., J. F., Hult, G. T., Ringle, C. M., \& Sarstedt, M. (2017). A primer on partial least squares structural equation modeling (PLS-SEM) (2e). Los Angeles: Sage Publications, Inc.

Hendeler, J., Ringle, C., \& Sinkovics, R. (2009). The use of partial least squares path modeling in international marketing. Advances in International Marketing, 20, 277-320.

Henseler, J., Ringle, C. M., \& Sarstedt, M. (2015). A new criterion for assessing discriminant validity in variance-based structural equation modeling. Journal of the Academy of Marketing Science, 43(1), 115-135.

Judge, T. A., Ilies, R., \& Scott, B. A. (2006). Work-family conflict and emotions: Effects at Work and at home. Personnel Psychology, 59(4), 779-814.

Khan, S. A., Lederer, A. L., \& Mirchandani, D. A. (2013). Top management support, collective mindfulness, and information systems performance. Journal of International Technology and Information Management, 22(1), 95-122.

Langer, E. J. (1989). Minding matters: The consequences of mindlessness-mindfulness. Advances in Experimental Social Psychology, 22, 137-173.

Mangal, S., \& Mangal, S. (2013). Research methodology in behavioral sciences. New Deli, India: PHI Learning Private Limited, Rimjhim House.

Nunnally, J. (1978). Psychometric theory. New York, NY: McGraw-Hill.

Peterson, A. (2014, December 18). The Sony Pictures hack, explained. Retrieved from The Washing Post: https://www.washingtonpost.com/news/the-switch/wp/2014/12/18/the-sony-pictures-hackexplained/?utm_term=.f98ad41e7acb

Ringle, C. M., Wende, S., \& Becker, J.-M. (2015). SmartPLS 3. Bönningstedt, Germany. 
Straub, D., Boudreau, M.-C., \& Gefen, D. (2004). Validation guidelines for IS positivist research. Communications of the Association for Information Systems, 13, 380-427.

Swanson, E., \& Ramiller, N. C. (2004). Innovating mindfully with information technology. MIS Quarterly, 28(4), 553-582.

Target. (2014, January 20). Target provides update on data breach and financial performance. Retrieved from Target: https://corporate.target.com/press/releases/2014/01/target-provides-update-on-databreach-and-financia

Trantopoulos, K., von Krogh, G., Wallin, M. W., \& Woerter, M. (2017). External knowledge and information technology: Implications for process innovation performance. MIS Quarterly, 41(1), 287-300.

Weick, K. E., \& Sutcliffe, K. M. (2001). Managing the unexpected: Assuring high performance in an age of complexity. San Francisco, CA: Jossey-Bass. 


\section{About the Authors}

René Moquin is an Assistant Professor in the Department of Computer Information Technology of the Neil Griffin College of Business at Arkansas State University.

Copyright ( 2019 by the Association for Information Systems. Permission to make digital or hard copies of all or part of this work for personal or classroom use is granted without fee provided that copies are not made or distributed for profit or commercial advantage and that copies bear this notice and full citation on the first page. Copyright for components of this work owned by others than the Association for Information Systems must be honored. Abstracting with credit is permitted. To copy otherwise, to republish, to post on servers, or to redistribute to lists requires prior specific permission and/or fee. Request permission to publish from: AIS Administrative Office, P.O. Box 2712 Atlanta, GA, 30301-2712 Attn: Reprints or via e-mail from ais@aisnet.org. 